THE ROAD TAKEN 

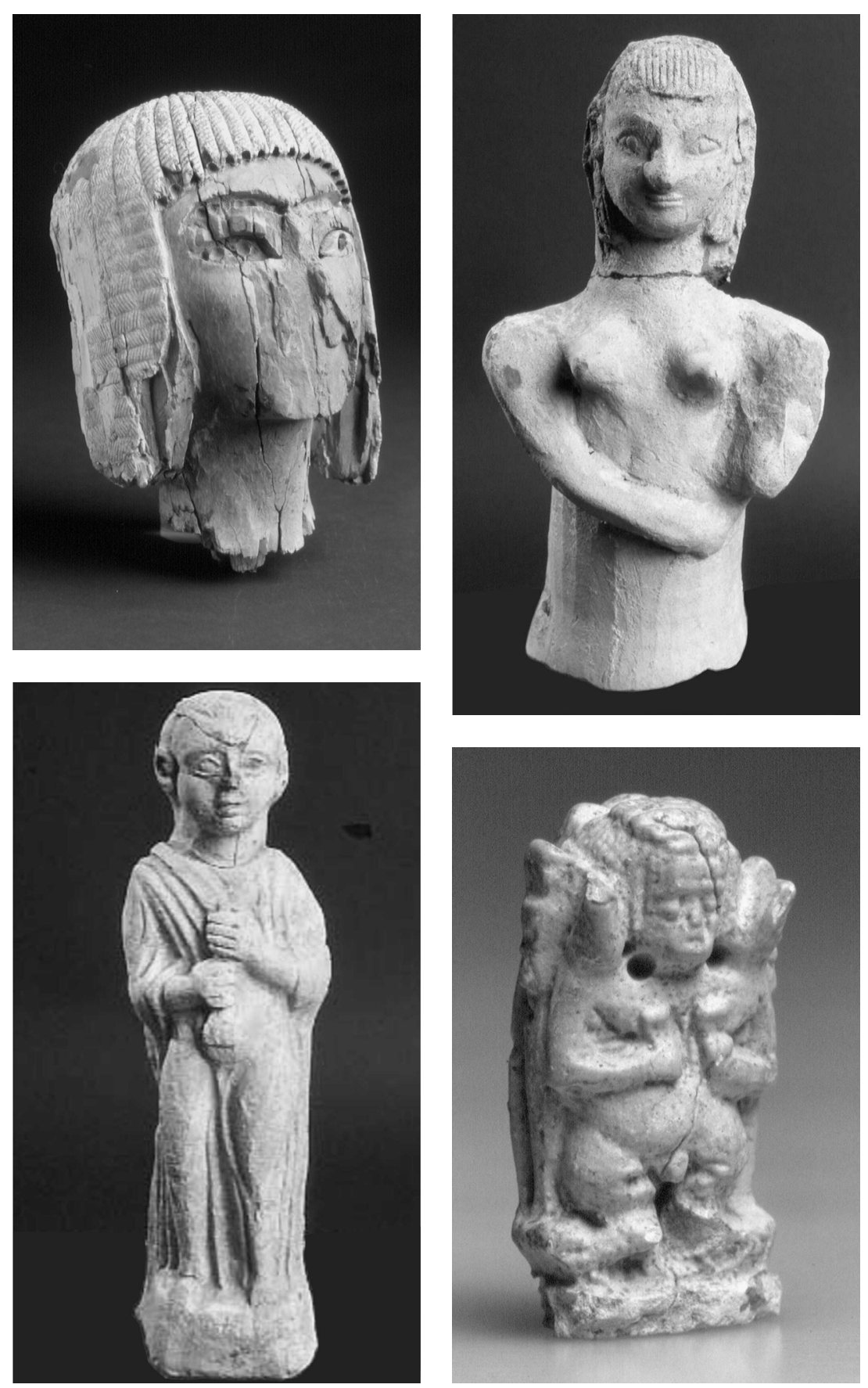


\section{The Road Taken}

An Archaeologist's Journey to the Land of the Bible

SEYMOUR (SY) GITIN 
Names: Gitin, Seymour, author.

Title: The road taken : an archaeologist's journey to the land of the Bible / Seymour (Sy) Gitin.

Description: University Park, Pennsylvania : Eisenbrauns ; Jerusalem : Albright Institute of Archaeological Research, [2021] | Includes bibliographical references and index.

Summary: "A narrative of the events that led the author to a career in archaeology and eventually to 34 years as director of the W. F. Albright Institute of Archaeological Research in Jerusalem"-Provided by publisher.

Identifiers: LCCN 2021002996 | ISBN 9781646021345 (hardback)

Subjects: LCSH: Gitin, Seymour. | W.F. Albright Institute of Archaeological ResearchBiography. | W.F. Albright Institute of Archaeological Research-History. |

Archaeologists-United States-Biography. | Israel-Antiquities. |

LCGFT: Autobiographies.

Classification: LCC DS115.9.G57 A3 2021 | DDC 933.0072/O2 [B]—dc23

LC record available at https://lccn.loc.gov/2021002996

Copyright $@ 2021$ Seymour Gitin

All rights reserved

Printed in the United States of America

Published by The Pennsylvania State University Press,

University Park, PA 16802-1003

Eisenbrauns is an imprint of The Pennsylvania State University Press.

The Pennsylvania State University Press is a member of the Association of University Presses.

It is the policy of The Pennsylvania State University Press to use acid-free paper. Publications on uncoated stock satisfy the minimum requirements of American National Standard for Information Sciences-Permanence of Paper for Printed Library Material, ANSI Z39.48-1992.

Figures on Page ii

Top left: Ivory head of top of harp, Ekron, Temple Complex 650, Sanctuary, Room p, (Obj. No. 7285), Stratum IB, late 7th c. BCE. Photo by Z. Radovan.

Top right: Torso of ceramic bell-shaped Phoenician-type figurine, Ekron, Temple Complex 650, Sanctuary, Cella Room t, and head of figurine, entrance to Sanctuary,Columned Hall, Room u (Obj. Nos. 7309, 7146), Stratum IB, Late 7th c. BCE. Photo by Z. Radovan.

Bottom left: Figurine, standing youth holding a strap, Ekron, Building 850, Debris VSW.72014, (Obj. No. 7529), Persian period. Photo by Z. Radovan.

Bottom right: Amulet Ptah patecus, Ekron, Temple Complex 650, Room x, (Obj. No 6652) Stratum IB, Late 7 th c. BCE. Photo by Z. Radovan. 
To Cherie,

with love and affection for our more than forty-five wonderful years together, and without whose support much of what is described in these memoirs would never have happened. 
